\title{
Losses in Mass and Sensory Properties of Thermally Treated Lamb Meat
}

\author{
Jasmina Stojiljkovic ${ }^{1, *}$, Zoran Stojiljkovic ${ }^{2}$ \\ ${ }^{1}$ Department of Food Technology, College of Applied Studies, Academy of Vocational Studies, Vranje, Republic of Serbia \\ ${ }^{2}$ Meat Science, Faculty of Agricultural Sciences and Food, University "St Cyril and Methodius", Skopje, Macedonia
}

Email address:

jasmina_vranje@yahoo.com (J. Stojiljkovic), zoran140366@gmail.com (Z. Stojiljkovic)

*Corresponding author

To cite this article:

Jasmina Stojiljkovic, Zoran Stojiljkovic. Losses in Mass and Sensory Properties of Thermally Treated Lamb Meat. International Journal of Food Engineering and Technology. Vol. 3, No. 2, 2019, pp. 25-30. doi: 10.11648/j.ijfet.20190302.12

Received: July 23, 2018; Accepted: August 2, 2018; Published: November 13, 2019

\begin{abstract}
In this research, three groups of 12 lambs (6 male and 6 female) of the Pirot improved race were examined. The first group of lambs was fattened for 60 days, the second 120 and the third 180 days. Nutrition of the lamb to rejection (40 days) is the mother's milk. After 40 days, it switched to pelleted concentrate (with $18 \%$ protein) and a quality hay, which was ad libidum as the concentrate. At the end of the fattening, the lamb is slaughtered by the usual technique. The objectives of this study were 1) to determine the effect of fattening and a gender on sensory properties of baking lamb meat, and 2) to determine the effect of heat processing on sensory attributes and cooking and breaking loss. Losses on the weight of the cooking and baking, between the first and third, as well as between the second and third groups show a significant difference $(\mathrm{P}<0,01)$ both in male and female lambs. There are no significant differences for male and female lambs in all three groups in terms of loss mass of meat (\%) during the heat treatment. During the cooking, ie, the roasting of the meat, minimal, insignificant, differences in the loss of mass among the male and female lambs were observed. It can be concluded that the gender of lambs has no significant effect on the loss in meat mass during heat treatment. The smell, taste, and softness in all three groups are not significant in male and female lambs. Mean juicy values are significant $(\mathrm{P}<0.01)$ higher for the second in relation to the first group in both genders lambs. The sensory characteristics of roasted meat of female lambs in the three groups were assessed with higher grades compared to male lamb meat. Statistically significant differences between the genders in terms of meat taste were determined in the second $(\mathrm{P}<0.05)$ and the third $(\mathrm{P}<0.01)$ group of lambs. It can be concluded that thermally treated meat of female lambs has better sensory qualities than the male lamb's meat.
\end{abstract}

Keywords: Loss Mass, Sensory Properties, Termally Treated Meat, Fattening, Gender, Lamb

\section{Introduction}

Meat preferences of consumers are associated with socioeconomic factors, ethics or religious beliefs and tradition [1]. For instance, a highly preferred meat flavour in one culture, region or country may be perceived as less preferable or unacceptable in another [2]. Red meat consumers generally tend to think that meat from pasture raised lambs is more tasty and healthy as these lambs grow in a natural environment and consume less concentrate feed when compared with lamb meat from sheepfold raised lambs [1].

Lamb meat has a low consumption because of its specific taste and tenderness [3]. There are many pre- and post- mortem factors that may alter the organoleptic characteristics of the meat. In particular, the diet of lambs is a factor that influences these organoleptic characteristics [4-7]. The differences in the sensory characteristics of the meatin ruminants may be affected if they are exclusively fed on forages of cereals [8].

Along with nutritional attributes, sensory characteristics are a key factor strongly influencing the demand and willingness to pay decisions of lamb consumers [9]. Numerous studies in meat sheep have concluded that sensory traits were mainly influenced by animal age and feeding regimes [10-13].

Group of authors observed that EU consumers preferred lamb meat from concentrate or mixed systems 
(concentrateand pasture) to meat of lambs fed only on pasture [14]. Furthermore, reported that meat from fattier carcasses had higher flavour intensity [15-16].

According to the Polish nutrition standards, lamb meet is recognized as a significant sourceof iron for children, youth, men and women (excluding groups aged up to 50 years) forw hich the recommended dietary allowances range from 10 to $15 \mathrm{mg}$ [17].

The heat treatment of the food is carried out to ensure product appropriate eatingqualities including taste, flavour and texture, extend the product shelf life throughheat inactivation of enzymes and microorganisms and finally, to increase the nutrient bioavailability, particularly proteins, [18-19].

Cooked samples were analyzed for their color. Texture, odour, tenderness, juiciness and overall acceptability by 10 trained and untrained panelists. Panelists were selected among department staff and students and trained according to the American Meat Science Association guidelines [20]. Sensory evaluation was carried out in individual booths under controlled conditions of light, temperature and humidity. Sensory qualities of the samples were evaluated after cook using a 5-point scoring method. Sensory scores were 5 for excellent, 4 for very good, 3 for good, 2 for fair and 1 for poor [21]. Sensory characteristics of cooked samples were assessed by seven panellists using an eight point category scale described by [22]. The panellists assessed lamb odour intensity, tenderness, juiciness, flavour intensity, flavour quality and overall acceptability (scale $1=$ no odour, extremely tough, extremely dry, no flavour, dislike flavour extremely and dislike extremely; scale 8=very strong lamb odour, extremely tender, extremely juicy, very strong flavour, like flavour extremely and like extremely), [22].

Overall acceptability scores given to lamb could be reflection of the meat tenderness, flavour intensity and quality perception of panelists [23]. In particular, flavour which can be the determining feature in acceptance or rejection of the meat, is an important aspect for consumer preferences [2]. The highest scores in terms of flavour intensity and quality were given to meat from winter rearing and autumn rearing lambs, while there were no significant differences in tenderness scores among whole groups [24]. This is also supported by Pearson correlation results which are positive and significant between flavour quality and overall acceptability and flavour intensity and overall acceptability in agreement with the results reported by [14, 23].

The colour of meat is one of the most important quality attributes evaluated by consumers upon purchase. The colour of meat is determined by two major pigments i.e. myoglobin and haemoglobin, by cytochrome $\mathrm{C}$, cobalamin, and adipose tissue. The intensity of colour depends on the pigment concentration (indirectly - on heme content) and the species, breed, sex, age of animals as well as on type of muscle or muscle fibre [25-26]. Meat colour after the heat treatment relies on $\mathrm{pH}$, species, fat content, packaging conditions, freezingprocess, added substances and fixing treatment, such as ionization or high pressure [19, 27].

Thirty male Suffolk lambs $(37.2 \pm 5.4 \mathrm{~kg}$ live weight) were used to evaluate the carcass characteristics and meat sensory. Organoleptic characteristics did not present differences, except juiciness $(\mathrm{P}=.002)$, [28].

The cooking loss following the heat treatment was estimated by the difference in the muscle sample weight before and after the thermal treatment.Significant increase $(\mathrm{P} \leq 0.01)$ of cooking loss with the increasing thermal treatment temperature was observed and, notably, at $90^{\circ} \mathrm{C}$ threefold higher cooking loss was detected as compared to $60^{\circ} \mathrm{C}[29]$. Increasing of the processing temperature significantly affected meat colour by increasing lightness and hue, and reducing redness, yellowness, and saturation. Rising the temperature of treatment from $60^{\circ} \mathrm{C}$ to $90^{\circ} \mathrm{C}$ significantly increased the cooking loss from $9.1 \mathrm{~g} / 100 \mathrm{~g}$ to $36.2 \mathrm{~g} / 100 \mathrm{~g}$ [29].

\section{Materials and Methods}

\subsection{Location, Dietary Management and Animal Ethics Permit}

The experiment included a total of 36 lambs from the purified ennobled sheep divided into 3 groups ( 6 males and 6 females), according to the duration of the fattening period, as follows:I group 60 days fattening; II group 120 days fattening and III group 180 days fattening. The test is performed only in lambs, lambing as unions, at the farm Djumruk on Vlasina Lake, Republic of Serbia, located at an altitude of $1.250 \mathrm{~m}$.

The daily meal of sheep breastfeeding from the beginning of the experiment to the $40^{\text {th }}$ day consisted of: seeds $1.8 \mathrm{~kg} /$ lamb; silage $1.5 \mathrm{~kg} /$ lamb and concentrate $0.5 \mathrm{~kg} /$ lamb. In the first 10 days, the mother's milk was present in the diet of the lambs, and from the $11^{\text {th }}$ day until the end of the fattening, all three groups of lambs had at their disposal a pelleted concentrate and a quality seeds at will, whose consumption was monitored and recorded every day. The lambing period of the lambs was completed on the $40^{\text {th }}$ day of their life.In the diet of all three groups of lambs, the pelleted concentrate and the quality seeds were represented until the end of the experiment and that no group was pasture or used any other foods.

After finishing the fattening the lambs were slaughtered in the slaughterhouse Jugokop- Bujanovac, Republic of Serbia, which had an export character, which means that all necessary prerequisites for processing and storage of the meat received were met, according to the strict European standards. Each group of lambs from farm to slaughterhouse was transported by truck. Twelve hours before slaughter, food was broken at the lambs, while water was available until loading in a truck. Immediately after the landing of the lambs in the livestock depot, a visual inspection was carried out by the veterinary inspection, which concluded that all the lambs were in good condition, with good health and that they could 
go to slaughter.

\subsection{Slaughter and Sampling}

The slaughter of the lambs is carried out according to the technological procedure, according to the following phases: preparing lamb for slaughter; raising to the track; bleeding; removing the skin; evisceration and cooling. After taking the linear measures is done cutting left half on basic parts, and their measurement. Then, the calculated values of the yield of individual tissues (meat, fat, bones) in the main parts of the carcass. After slaughtering the lambs, the primary processing and cooling, the halves are cut into the main parts. The carcasses are cut into the following main parts: round, loin, back, shoulder, neck, breast, ribs, foreshank, belly and lower leg.

\subsection{Sensory Evaluation Test of Roasted Meat}

Samples for determining the sensory properties of fresh meat were analyzed at the central laboratory of the Institute for Animal Husbandry in Zemun Pole, in the Republic of Serbia. The examined sensory properties of roasted meat are: smell, taste, tenderness, juiciness with points from 0 to 5 .

\subsection{Mass Loss Test During Thermal Treatment}

A piece of meat weighing $40 \mathrm{~g}$ (approximately in the same shape) is boiled for $10 \mathrm{~min}$ in boiling water (in a $400 \mathrm{~mL}$ cup). Pour $100 \mathrm{~mL}$ of distilled water and when the water starts to boil, place the piece of meat. The piece of meat is measured immediately before placing in the cup, with an accuracy of $\pm 0.1 \mathrm{~g}$. After cooking, the meat is removed from the water, wiped with a filter paper and weighed. The difference in mass before and after digestion expressed in $\%$ is a weight loss in cooking. A piece of meat weighing $40 \mathrm{~g}$ is wrapped in aluminum foil, placed in a heated oven at $250^{\circ} \mathrm{C}$ for $20 \mathrm{~min}$. After the baking is completed, the sample is removed, the foil removed, the sample is erased with a filter paper and measured. The difference in mass before and after grilling, expressed in $\%$, is a weight loss in baking.

\subsection{Statistical Analysis}

Variational statistical analysis was performed by analyzing the variance of two-factorial experiment $(3 \times 2)$, according to [30]. The differences in the mean values were tested with the Tukey test.

\section{Results and Discussion}

\subsection{Losses in the Mass During Thermal Treatment of Lamb Meat}

Losses in the mass during the heat treatment of the meat (cooking and baking) are presented in Tables 1,2 and 3.

Table 1. Loss in the mass during the heat treatment of the male lamb meat (\%).

\begin{tabular}{|c|c|c|c|c|c|c|c|c|c|}
\hline \multirow{3}{*}{ Examined characteristics } & \multicolumn{9}{|l|}{ Group } \\
\hline & \multicolumn{3}{|l|}{ I } & \multicolumn{3}{|l|}{ II } & \multicolumn{3}{|l|}{ III } \\
\hline & $\mathbf{X}$ & SD & $\mathbf{C v}$ & $\mathbf{x}$ & SD & $\mathrm{Cv}$ & $\mathbf{X}$ & SD & $\mathrm{Cv}$ \\
\hline Weight loss in cooking & $31.21^{\mathrm{a}}$ & 1.38 & 4.41 & $31.41^{\mathrm{ab}}$ & 1.15 & 3.68 & $29.56^{\mathrm{c}}$ & 1.21 & 4.09 \\
\hline Weight loss in baking & $34.75^{\mathrm{a}}$ & 0.47 & 1.34 & $34.27^{\mathrm{ab}}$ & 1.05 & 3.05 & $33.27^{\mathrm{c}}$ & 1.17 & 3.52 \\
\hline
\end{tabular}

abc-The mean values in a single row marked with different letters are significantly different $(\mathrm{P}<0.01)$

Table 2. Loss in the mass during the heat treatment of the female lamb meat (\%).

\begin{tabular}{|c|c|c|c|c|c|c|c|c|c|}
\hline \multirow{3}{*}{ Examined characteristics } & \multicolumn{9}{|l|}{ Group } \\
\hline & \multicolumn{3}{|l|}{$\mathbf{I}$} & \multicolumn{3}{|l|}{ II } & \multicolumn{3}{|l|}{ III } \\
\hline & $\mathbf{X}$ & SD & $\mathbf{C v}$ & $\mathbf{x}$ & SD & $\mathrm{Cv}$ & $\mathbf{X}$ & SD & $\mathrm{Cv}$ \\
\hline Weight loss in cooking & $31.79^{\mathrm{a}}$ & 1.79 & 5.64 & $31.46^{\mathrm{ab}}$ & 1.75 & 5.57 & $29.56^{\mathrm{c}}$ & 0.82 & 2.77 \\
\hline Weight loss in baking & $35.18^{\mathrm{a}}$ & 1.26 & 3.57 & $34.58^{\mathrm{ab}}$ & 1.11 & 3.19 & $33.45^{\mathrm{c}}$ & 0.94 & 2.80 \\
\hline
\end{tabular}

abc-The mean values in a single row marked with different letters are significantly different $(\mathrm{P}<0.01)$

Losses on the weight of the cooking and baking, between the first and third, as well as between the second and third groups show a significant difference $(\mathrm{P}<0.01)$ both in male and female lambs (Table 1 and Table 2$)$.

Table 3. Differences between gender of lambs in relation to loss of mass of meat during heat treatment (\%).

\begin{tabular}{|c|c|c|c|c|}
\hline Examined characteristics & Group & Male & Female & Difference \\
\hline \multirow{3}{*}{ Weight loss in cooking } & I & 31.21 & 31.79 & $0.58^{\mathrm{ns}}$ \\
\hline & II & 31.41 & 31.46 & $0.05^{\mathrm{ns}}$ \\
\hline & III & 29.56 & 29.56 & $0.00^{\mathrm{ns}}$ \\
\hline \multirow{3}{*}{ Weight loss in baking } & I & 34.75 & 35.18 & $0.43^{\text {ns }}$ \\
\hline & II & 34.27 & 34.58 & $0.31^{\mathrm{ns}}$ \\
\hline & III & 33.27 & 33.45 & $0.18^{\mathrm{ns}}$ \\
\hline
\end{tabular}

ns - not significant

There are no significant differences in male and female lambs in all three groups in terms of loss mass of meat (\%) 
during the heat treatment (Table 3). During the cooking, ie, the roasting of the meat, minimal, insignificant, differences in the loss of mass among the male and female lambs were observed.

It can be concluded that the gender of lambs has no significant effect on the loss in meat mass during heat treatment.

\subsection{Sensory Properties of Roasted Meat}

The smell, taste, and softness in all three groups (Tables 4 and 5) are not significant for male and female lambs. Mean juicy values are significant $(\mathrm{P}<0.01)$ higher in the second in relation to the first group in both sexes lambs (Tables 4 and $5)$.

Table 4. Sensory evaluation of roast meat in the case of male lambs (points from 0 to 5).

\begin{tabular}{|c|c|c|c|c|c|c|c|c|c|}
\hline \multirow{3}{*}{ Examined characteristics } & \multicolumn{9}{|c|}{ Group } \\
\hline & \multicolumn{3}{|c|}{ I } & \multicolumn{3}{|l|}{ II } & \multicolumn{3}{|l|}{ III } \\
\hline & $\mathbf{X}$ & SD & $\mathrm{Cv}$ & $\mathbf{X}$ & SD & $\mathrm{Cv}$ & $\mathbf{X}$ & SD & $\mathrm{Cv}$ \\
\hline Smell & $4.09^{\mathrm{a}}$ & 0.19 & 4.63 & $4.29^{\mathrm{a}}$ & 0.43 & 10.04 & $3.98^{\mathrm{a}}$ & 0.20 & 5.13 \\
\hline Taste & $4.03^{\mathrm{a}}$ & 0.22 & 5.53 & $4.11^{\mathrm{a}}$ & 0.12 & 3.02 & $3.94^{\mathrm{a}}$ & 0.22 & 5.69 \\
\hline Tenderness & $4.04^{\mathrm{a}}$ & 0.55 & 13.61 & $4.33^{\mathrm{a}}$ & 0.41 & 9.43 & $4.03^{\mathrm{a}}$ & 0.17 & 4.25 \\
\hline Juiciness & $4.01^{\mathrm{a}}$ & 0.22 & 5.37 & $4.29^{b}$ & 0.33 & 7.74 & $4.13^{\mathrm{ab}}$ & 0.26 & 6.35 \\
\hline Average rating & $4.04^{\mathrm{a}}$ & 0.17 & 4.32 & $4.26^{\mathrm{b}}$ & 0.14 & 3.23 & $4.02^{\mathrm{ac}}$ & 0.13 & 3.15 \\
\hline
\end{tabular}

abc-The mean values in a single row marked with different letters are significantly different $(\mathrm{P}<0.01)$

Table 5. Sensory evaluation of roast meat in the case of female lambs (points from 0 to 5).

\begin{tabular}{|c|c|c|c|c|c|c|c|c|c|}
\hline \multirow{3}{*}{ Examined characteristics } & \multicolumn{9}{|c|}{ Group } \\
\hline & \multicolumn{3}{|l|}{ I } & \multicolumn{3}{|l|}{ II } & \multicolumn{3}{|l|}{ III } \\
\hline & $\mathbf{x}$ & SD & $\mathbf{C v}$ & $\mathbf{x}$ & SD & $\mathbf{C v}$ & $\mathbf{x}$ & SD & $\mathbf{C v}$ \\
\hline Smell & $4.23^{\mathrm{a}}$ & 0.32 & 7.54 & $4.42^{\mathrm{a}}$ & 0.26 & 5.84 & $4.13^{\mathrm{a}}$ & 0.25 & 6.06 \\
\hline Taste & $4.11^{\mathrm{a}}$ & 0.26 & 6.22 & $4.42^{\mathrm{a}}$ & 0.13 & 2.93 & $4.44^{\mathrm{a}}$ & 0.31 & 6.96 \\
\hline Tenderness & $4.08^{\mathrm{a}}$ & 0.30 & 7.42 & $4.42^{\mathrm{a}}$ & 0.34 & 7.73 & $4.15^{\mathrm{a}}$ & 0.20 & 4.88 \\
\hline Juiciness & $3.98^{\mathrm{a}}$ & 0.20 & 5.13 & $4.33^{b}$ & 0.20 & 4.72 & $4.32^{\mathrm{ab}}$ & 0.31 & 7.20 \\
\hline Average rating & $4.11^{\mathrm{a}}$ & 0.19 & 4.62 & $4.40^{\mathrm{b}}$ & 0.11 & 2.49 & $4.26^{\mathrm{ac}}$ & 0.12 & 2.89 \\
\hline
\end{tabular}

abc-The mean values in a single row marked with different letters are significantly different $(\mathrm{P}<0.01)$

The sensory characteristics of roasted flesh of female lambs in the three groups were assessed with higher grades compared to male lamb meat (Table 6). Statistically significant differences between the sexes in terms of meat taste were determined in the second $(\mathrm{P}<0.05)$ and the third $(\mathrm{P}<0.01)$ group of lambs. It can be concluded that the meat of female lambs has better sensory qualities than the male lamb's meat.

Table 6. Comparison of the sensory evaluation of the roast meat according to gender of the lambs (points 0 to 5).

\begin{tabular}{|c|c|c|c|c|}
\hline Examined characteristics & Group & Male & Female & Difference \\
\hline \multirow{3}{*}{ Smell } & I & 4.09 & 4.23 & $0.14^{\mathrm{ns}}$ \\
\hline & II & 4.29 & 4.42 & $0.13^{\mathrm{ns}}$ \\
\hline & III & 3.98 & 4.13 & $0.15^{\mathrm{ns}}$ \\
\hline \multirow{3}{*}{ Taste } & I & 4.03 & 4.11 & $0.08^{\text {ns }}$ \\
\hline & II & 4.11 & 4.42 & $0.31^{*}$ \\
\hline & III & 3.94 & 4.44 & 0.50 ** \\
\hline \multirow[t]{2}{*}{ Tenderness } & II & 4.33 & 4.42 & $0.09^{\mathrm{ns}}$ \\
\hline & III & 4.03 & 4.15 & $0.12^{\mathrm{ns}}$ \\
\hline \multirow{3}{*}{ Juiciness } & I & 4.01 & 3.98 & $0.03^{\mathrm{ns}}$ \\
\hline & II & 4.29 & 4.33 & $0.04^{\text {ns }}$ \\
\hline & III & 4.13 & 4.32 & $0.19^{\text {ns }}$ \\
\hline \multirow{2}{*}{ Average rating } & II & 4.26 & 4.40 & $0.14^{\mathrm{ns}}$ \\
\hline & III & 4.02 & 4.26 & $0.24^{*}$ \\
\hline
\end{tabular}

* $-\mathrm{P}<0.05 ;{ }^{* *}-\mathrm{P}<0.01 ; \mathrm{ns}-$ not significant

Based on the results in Table 6, it can be concluded that the thermally treated meat of the female lamb has better sensory properties than the meat of the male lamb.

The increased amount of intramuscular fat and the deposition of larger layers of fat intramuscularly, in heavier lambs, is favorably reflected on the meseness of the casrcass (muscle and fat tissue together), on the commercial and organoleptic properties of fresh (marbles) and roasted meat (culinary properties). This conclusion reinforces the more favorable organoleptic qualities of roasted meat in heavier lambs (lambs of the second group), especially in terms of flavor. Sensory properties do not depend on the weight of the 
carcasses, with the exception of the juiciness of the meat.

\section{Conclusion}

The fattening and gender of the lamb affects the sensory properties of the roasted meat and thermal losses in mass. The meat of the heavier lambs shows a less thermal loss of mass and a greater culinary value than the light lamb meat. By slaughtering heavier lambs, more favorable results are achieved in terms of meat quality. No qualitative indicator of the value of meat gives preference to the meat of light lambs. Losses in a mass during the heat treatment of the meat (cooking, ie roasting) are the smallest among the meat of the third group of lambs. Differences in loss of mass between the first and the third, as well as between the second and the third groups are significant $(\mathrm{P}<0.01)$. The lamb gender has no significant effect on the loss of meat on the meat during cooking. Culinary properties are the best in roasted meat from the second group of lambs. It can be concluded that thermally treated meat of female lambs has better sensory qualities than the male lamb's meat. The future research will focus on the comparison of the sensory properties of fresh and thermally treated for lamb meat.

\section{References}

[1] Font i Furnols, M., and Guerrero, L. (2014). Consumer preference. Behavior and perception about meat products: An overview. Meat Sci., 98: 361-371.

[2] Schreurs, N. M., Lane, G. A., Tavendale, M. H., Barry, T. N. and McNabb, W. C. (2008). Pastoral flavour in meat products from ruminantsfed fresh forages and its amelioration by forage condensedtannins. Anim. Feed Sci. Technol., 146: 193221.

[3] Young, O. A., Reid, D. H., Smith, M. E. and Braggins, T. J. (1994). Sheepmeat odour and flavour. In: Shahidi F, editor. Flavor Meat, Meat Prod Springer US. p. 71-97.

[4] Arsenos, G., Banos, G., Fortomaris, P., Katsaounis, N., Stamataris, C., Tsaras, L., et al. (2002). Eating quality of lamb meat: Effects of breed, sex, degree of maturity and nutritionalmanagement. Meat Sci., 60: 379-387.

[5] Fisher, A. V., Enser, M., Richardson, R. I., Wood, J. D., Nute, G. R., Kurt, E., et al. (2000). Fatty acidcomposition and eating quality of lamb types derived from four diverse breed $\mathrm{x}$ production systems. Meat Sci., 55: 141-147.

[6] Priolo, A., Micol, D., Agabriel, J., Prache, S. and Dransfield, E. (2002). Effect of grass or concentratefeeding systems on lamb carcass and meat quality. Meat Sci., 62: 179-185.

[7] Rousset-Akrim, S., Young, O. A. and Berdagué, J. L. (1997). Diet and growth effects in panelassessment of sheepmeatodour and flavour. Meat Sci., 45: 169-181.

[8] Melton, S. L (1990). Effects of feeds on flavor of red meat: A review. J Anim Sci., 68: 4421-4435.

[9] Pethick, D (2006). Eating quality of commercial meat cuts from Australian lambs and sheep. In Proceedings of the New Zealand Society of Animal Production.
[10] Della Malva, A., Albenzio, M., Annicchiarico, G., Caroprese, M., Muscio, A., Santillo, A. and Marino, R. (2016). Relationship between slaughtering age, nutritional and organoleptic properties of Altamurana lamb meat. Small Ruminant Research 135: 39-45.

[11] De Brito, G. F., McGrath, S. R., Holman, B. W. B., Friend, M. A., Fowler, S. M., van de Ven, R. J. and Hopkins, D. L. (2016). The effect of forage type on lamb carcass traits, meat quality and sensory traits. Meat Sci., 119: 95-101.

[12] Girard, M., Dohme-Meier, F., Silacci, P., AmpueroKragten, S., Kreuzer, M. and Bee, G. (2015). Forage legumes rich in condensed tannins may increase n-3 fatty acid levels and sensory quality of lamb meat. Journal of the Science of Food and Agriculture 96 (6): 1923-1933.

[13] Erasmus, S. W., Hoffman, L. C., Muller, M. and van der Rijst, M. (2016). Variation in the sensory profile of South African Dorper lamb from extensive grazing systems. Small Ruminant Research 144: 62-74.

[14] Font i Furnols, M., Realini, C. E., Guerrero, L., Oliver, M. A., Sañudo, C., Campo, M. M., Nute, G. R., Cañeque, V., Álvarez, I., San Julián, R., Luzardo, S., Brito, G. and Montossi, F. (2009). Acceptabilityof lamb fed on pasture, concentrate or combinations ofboth systems by European consumers. Meat Sci., 81: 196-202.

[15] Sañudo, C., Enser, M. E., Campo, M. M., Nute, G. R., Maria, G., Sierra, I. and Wood, J. D. (2000). Fatty acid composition and sensory characteristics of lamb carcasses from Britain and Spain. Meat Sci., 54: 339-346.

[16] Muela, E., Sañudo, C., Campo, M. M., Medel, I. and Beltrán, J. A. (2010). Effects of cooling temperature and hot carcass weight on thequality of lamb. Meat Sci., 84, $101-107$.

[17] Jarosz M (Ed.), (2012). Detary referencesfor the Polish population - the amendment. In Polish. Instytut Żywności i Żywienia, Warszawa.

[18] Tornberg, E (2005). Effects of heat on meat proteins Implications on structure and quality ofmeat products. Meat Sci., 70: 493-508.

[19] King, N. J. and Whyte, R. (2006) Does it look cooked? A review of factors that influence cooked meatcolour. Journal of Food Science 71 (4): 31-40.

[20] AMSA (1995). Research guidelines for cookery, sensory evaluation, and instrumental tenderness measurements of fresh meat. Chicago III. American Meat Science Association and Nutritional Live Stock and Meat Board.

[21] Rahman, S. M. E., Park, J., Song, K. B., Al-Harbi, N. A. and Oh, D. H. (2012). Effect of slightly acidic low concentration electrolyzed water on microbiological, physicochemical, and sensory quality of fresh chicken breast meat. Journal of Food Science 77 (1): 35-41.

[22] Sañudo, C., Nute, G. R., Campo, M. M., Maria, G., Baker, A., Sierra, I., Enser, M. E. and Wood, J. D. (1998). Assessment of commercial lamb meat quality by British and Spanish taste panels. Meat Sci., 48: 91-100.

[23] Ekiz, B., Yilmaz, A., Ozcan, M. and Kocak, O. (2012). Effect of production system on carcass measurement and meat quality of Kivircik lambs. Meat Sci., 90, 465-471. 
[24] Yalcintan, H., Ekiz, B., Kocak, O., Dogan, N., Akin, D. P. andYilmaz. A. (2017). Carcass and meat quality characteristics of lambs rearedin different seasons. Archives Animal Brreding 60: 225-233.

[25] Mancini, R. A. and Hunt M. C. (2005). Current research in meat colour. Meat Sci., 71: 100-121.

[26] Pannier, L., Pethick, D. W., Boyce, M. D., Ball, A. J., Jacob, R. H. and Gardner, G. E. (2014). Associations of genetic and non-genetic factors with concentrations of iron and zinc in the longissimus muscle of lamb. Meat Sci., 96: 1111-1119.

[27] Domaradzki, P., Skalecki, P., Florek, M. and Litwinczuk, A. (2011). Effect of freezing storage on physicochemical properties of vacuum-packed beef. In Polish, summary in English. Żywnoṡż. Nauka, Technologia Jakość 3 (76): 117126.
[28] Romero-Bernal, J., Morales Almaraz, E., Salem, A. Z. M., Mariezcurrena-Berasain, M. D., Jaramillo-López, E. and González-Ronquillo, M. (2014). Chemical Composition, Carcass and Sensory Characteristics of Grazing Lambs Meat, Supplemented with Different Protein Sources. Annual Research \& Review in Biology 4 (13): 2174-2183.

[29] Florek, M., Junkuszew, A., Greguła-Kania, M., Bojar, W., Kaliniak, A., Bracik, K., Krupa, P. and Gruszecki, M. T. (2016). Effect of sex, muscle, and processing temperatureon heme iron content in lamb meat. Animal Science Papers and Reports 34 (3): 257-268.

[30] Sokal R. R. and Rohlf J. F. (1995). Biometry. Freeman and Company. New York. 